\title{
CRISPR/Cas technology for crop improvement (review)
}

\author{
N. E. Volkova*, 0. 0. Zakharova \\ Cotecna Ukraine Ltd, 140-A Liustdorfska doroha, Odesa, 65114, Ukraine, \\ *e-mail: natalia.volkova@cotecna.com
}

\begin{abstract}
Purpose. To analyze the current state of crop improvement using CRISPR/Cas technology of genome modifications. Results. The history of the development of genome editing technologies with site-specific endonucleases is presented. The current state of plant varieties creation using these technologies was analyzed. It was shown that CRISPR/Cas technology of gene editing has already been adapted for 20 species of crops, for more than 150 genes associated with important traits. The practical implementation of this technology was presented on the example of rice, for which the greatest progress in the research and use of CRISPR/Cas technology was observed: the largest number of genes has been modified - 78; more than 20 varieties were obtained. Edited rice genes associated with such traits as grain size, grain number, plant height, male sterility, cesium accumulation, tolerance to abiotic and biotic stresses, and resistance to herbicides. The possibility of multiplex editing of a potentially unlimited number of genes was underlined. The situation on the regulation of plants created by genome editing technology was discussed: according to the decision of the European Union (EU) court, all EU regulations and restrictions on the cultivation and sale of products, in particular plant varieties, obtained using genome editing techniques are applied as well as to GMOs, while according to the USDA such plants, except parasitic plants, are not regulated as GMOs. Information on the statement, approved by leading scientists representing more than 90 European research centers and institutes for the study of plants and biological sciences was provided in support of genome editing technology. Conclusions. Among the genome editing technologies, CRISPR/Cas technology is one of the most powerful approaches, which has become extensively used in plant breeding due to such advantages as high accuracy and quality, efficiency and technical flexibility, relatively low cost compared to other methods. This available method allows obtaining non-transgenic plants with specified modifications, and it is possible to simultaneously "produce" mutations in several targets.
\end{abstract}

Keywords: genetic modification; genome editing; site-specific endonucleases; gene knockout.

\section{Introduction}

According to the data given in the report of the Food and Agriculture Organization of the United Nations (FAO), the problem of world hunger is getting worse, leveling up the achievements of previous years when its scale steadily decreased [1]. It is estimated that the number of people facing malnutrition has reached more than 820 million people (approximately one in nine people in the world).

FAO has identified 17 Sustainable Development Goals [2]. They are new international goals that changed the Development Goals on $01 / 01 / 2016$. They will determine national development policies in the next 15 years. Food and agriculture are in the focus of attention,

Nataliia Volkova

http://orcid.org/0000-0002-9333-4872

Olga Zakharova

https://orcid.org/0000-0003-1828-9044 starting with the elimination of poverty and hunger to the fight against climate change and the preservation of natural resources. The second goal is to eliminate hunger, ensure food security, improve nutrition and promote sustainable agriculture ("ZeroHunger world").

As the population grows (world population projected to reach 10 billion in 2050), the production of food, feeding stuff and biofuels should increase by $50 \%$. Extreme weather conditions, reduced availability of agricultural land, biotic and abiotic stresses limit agriculture and food production. The development and implementation of technologies contributing to the increase in yield plays an important role in solving the problems of humanity. Transgenic technologies have certainly made a significant contribution to crop improvement, but despite the enormous importance of genetically modified plants for food, discussions about their safety do not stop. 
The purpose of the review is to analyze the current state of crop improvement using CRIS$\mathrm{PR} /$ Cas technology of genome modifications.

\section{Results}

In the past decade, genome editing techniques with site-specific endonucleases have been used for precise changes in the genomes of plants and animals. These nucleases recognize a unique sequence and create doublestranded breaks in the target DNA. Further DNA integrity is restored through cellular repair mechanisms: by non-homologous ends joining or homologous recombination, resulting in the emergence of insertions / deletions (indels) and substitution of mutations in the target region, respectively [3].

The first generation of genome editing technology uses three types of nucleases: meganucleases, zinc finger nucleases, ZFN and nucleases designed on the basis of bacterial proteins - TAL effectors (transcription activator-like effector nucleases, TALENs) [4]. The procedures with the first generation of nucleases are laborious and time-consuming.

The second generation of genome editing is associated with CRISPR systems (Clustered Regulatory Interspaced Short Palindromic Repeats, short palindromic repeats arranged in groups evenly spaced from each other). The first CRISPR locus was found in the genome of Escherichia coli in 1987 [5]. In 2002, the casgenes of the CRISPR loci encoding Cas proteins (CRISPR associated protein) were discovered [6]. CRISPR-Cas-systems provide adaptive immunity in prokaryotes. In 2013, it was shown that artificial CRISPR-Cas systems can work not only in bacteria and in vitro, but also in eukaryotic cells [7]. Today, CRISPR technologies are considered to be the most important technological innovation in the life sciences since the invention of the polymerase chain reaction. CRISPR-Cas systems differ both structurally and functionally. The most popular CRISPR technology is associated with nuclease Cas9 and is characterized by relative simplicity and high efficiency of work in cells [8].

Detailed descriptions of editing technologies are fairly fully represented in scientific articles [9-13] and are more interesting for narrow specialists in molecular genetics. Therefore, attention in this review is devoted to the practical use of these technologies in improving crops (more on the example of rice).

The CRISPR/Cas technology of gene editing has already been adapted for almost 20 species of crops for more than 150 target genes of various traits [14]. The main modification option used is gene knockout, and targets are negative growth regulators; loss of their functionality leads to an increase in plant productivity, or factors determining sensitivity to pathogens. The intensive use of this approach is due, firstly, to the fact that this is the simplest and most accessible method of modification, and secondly, to the presence of fairly diverse target genes that negatively affect the economically valuable traits. Generalized lists of cultures and modified genes can be found in reviews (for example, [15, 16]).

The greatest progress in research and the use of CRISPR/Cas technology is observed in rice: the largest number of genes (78) was modified; more than 20 genetically edited varieties were obtained. Rice (Oryza sativa L.) for more than half of the world's population is the main crop. Also, due to the small size of the genome it is a genetically well-studied cereal crop - a model object for monocotyledonous plants. CRISPR/ Cas technology is used to edit rice genes associated with agronomically important traits, resistance to biotic and abiotic stresses.

Productivity. At the same time, three negative gene regulators associated with the grain size were knocked out - GW2, GW5, TGW6 [17]. Three simultaneously knockout genes resulted in a significant elongation of the grain compared with the result obtained with knockout of one or two genes.

Four genes, potentially related to productivity, are knocked out in rice: a negative regulator of grain number Gn1a; DEP1 gene (knockout leads to the formation of a dense erect panicle) negative regulator of grain size GS3; IPA1 plant architecture regulator (knockout leads to a decrease in tillering intensity, decrease in the number of unproductive shoots, increase in grain number, thickening and density of stems) [18]. Later on, knockout genotypes of seven rice varieties with GS3 and double ones for Gn1a and GS3 were obtained. In the knockout plants, an increase in the grain size and grain number was recorded. Productivity increased (by 3-7\%) in only three of the obtained variants, while in seven it decreased due to a decrease in the number of productive shoots [19].

Plant height. An increase in the grain weight and grain number requires resistance to lodging, which is ensured by the short stature or strength of the stem. In rice, through the knockout of the DEP1 gene, the height of the plant is reduced [18]. Also, low-growing phenotype was obtained as a result of single-nucleotide change in the $S L R 1$ gene, a repressor response to gibberellin [20].

Controlled male sterility. Forms with controlled male sterility are necessary for use in 
hybrid breeding. Thus, in 11 rice lines, the TMS5 gene, a negative regulator of thermosensitive genic male sterility, was knocked out and forms fertile at the optimum temperature, but completely sterile at $28{ }^{\circ} \mathrm{C}$ were obtained, what allowed to control the process of self-pollination in the case of using these lines in hybrid breeding [21]. From three rice varieties, lines knocked out by the GSA gene - a negative regulator of the photoperiod-sensitive genic male sterility were obtained [22]. Under shortday conditions pollen sterility was achieved in these lines, while under long-day conditions the plants were fertile.

Tolerance to abiotic stresses. Three rice genes OsPDS, OsBADH2, OsMPK encoding enzymes phytoene desaturase, betaine-aldehyde dehydrogenase and mitogen-activated protein kinase and participating in controlled responses to various abiotic stresses were modified [2325]. Plant annexins play an important role in environmental stresses responses. The role of the annexin gene OsAnn3 under the influence of cold stress was studied [26]. It was revealed that the survival of CRPISR-T1-mutant lines is reduced compared to wild-type plants under conditions of cold pretreatment.

Herbicide resistance. Single nucleotide change in the $A L S$ gene encoding acetolactate synthase led to an increase in the resistance to chlorsulfuron herbicide [27]. A modification of the C287 gene, responsible for herbicide resistance [28], was performed.

Cesium accumulation. The occurrence of radioactive cesium in food after a nuclear accident disturbing from the perspective of a threat to human health. Despite being present at low concentrations (below $\mu \mathrm{m}$ ) in polluted soils cesium can be readily absorbed by plants and transported to their edible parts. Such plant's ability to absorb cesium, even at low concentrations, significantly influenced rice production in Japan after the accident at the Fukushima Daiichi Nuclear Power Plant in 2011. In practice several strategies were introduced to reduce the cesium content in rice, such as removing contaminated soil or adapting farming methods, including special management of mineral fertilizers which have limited impact or harmful side effects. However the development of biotechnological approaches aimed at reducing the accumulation of cesium in rice remained a challenge. Using the CRISPR-Cas-editing for inactivation of the $\mathrm{K}^{+}$ transporter OsHAK1, the absorption of cesium by rice plants was sharply reduced [29]. In the experiment with soil that was highly contaminated with $137 \mathrm{Cs}+$, plants with blocked
OsHAK1 functioning showed a significant decrease in $137 \mathrm{Cs}+$ levels in roots and shoots. These results demonstrate the possibility of producing safe food in regions contaminated due to nuclear accidents.

Tolerance to potassium deficiency. Peroxiredoxins (Prxs) protect cells from various peroxides, play an important role in maintaining redox homeostasis, and are involved in the transmission of intracellular and intercellular signals. Using the CRISPR/Cas9 technology, the $O s P R X 2$ rice gene was studied to characterize the effect of 2-Cys Prxs on the K+ deficiency tolerance [30]. OsprX2 overexpression leads to stomatal closure and increases tolerance to $\mathrm{K}+$ deficiency, whereas the OsPRX2 knockout results in serious defects in the leaf phenotype and stomatal openings in the case of $\mathrm{K}+$ deficiency. Detection of the accumulation of $\mathrm{K}+$, the antioxidant activity of transgenic plants with $\mathrm{K}+$ deficiency confirmed that OsPRX2 is a potential target for creating plants with increased tolerance to potassium deficiency.

Nitrogen uptake. A single nucleotide change in the NRT1.1B gene, which encodes a nitrogen transporter, increased the efficiency of nitrogen assimilation [20].

Tolerance to biotic stresses. The mutation in the ethylene-dependent transcription factor OsERF922 led to an increase in resistance against the underlying rice disease, Rice blast, caused by the fungus Magnaporthe oryzae [31]. The targets for CRISPR/Cas-directional knockout are genes that cause sensitivity to the disease. Two knockout mutants for OsSWEET13 gene of susceptibility to bacterial burn, caused by Xanthomonas oryzae pv. oryzae, were developed [32]. This led to increased resistance in rice indica IR24. As a result of knockout of the ERF922 gene forms resistant to rice blast were obtained [33].

Editing of quantitative trait loci. It should be noted that such important traits as yield and tolerance to abiotic stresses are controlled by two or more genes. Numerous studies have focused on the mapping of quantitative trait loci (QTL) that control these agronomically important traits. Such identified QTL regions began to be introduced into elite lines to develop efficient varieties. However, such introgression is unacceptable if the QTL is closely associated with untargeted regions, since their introduction into the elite line can lead to harmful consequences. CRISPR/Cas technology is a powerful tool for studying rare mutations in such cases. Thus, the functioning of QTLs associated with the size (GS3) and the number $(G n 1 a)$ of grains in rice varieties was investi- 
gated using CRISPR/Cas9-mediated QTL editing approach [19]. It has been revealed that identical QTLs can have very diverse and opposite effects on different genetic backgrounds.

Multiplexed gene editing. CRISPR/Cas technology also enables the multiplex editing of a potentially unlimited number of genes [34, 35]. This is demonstrated by the successful editing of eight agronomically important rice genes simultaneously: $B A D H 2$ (betaine aldehyde dehydrogenase 2), DEP1 (dense and erect panicle 1), Gn1a (grain number), GS3 (length and weight of grain), GW2 (width and weight of grain), $H d 1$ (heading date 1), EP3 (erect panicle), LPA1 (loose plant architecture 1) [26]. Five of these genes (DEP1, EP3, Gn1a, GS3, GW2) are associated with grain yield, the $B A D H 2$ gene with aroma, the $H d 1$ gene with photoperiod, and the LPA1 gene regulates the architecture of the plant. With the help of a single genetic transformation, not only plants obtained containing mutations in eight genes, but also mutants with various combinations of genes were created. In addition, both homozygous and heterozygous genotypes were obtained by eight genes.

So, genome editing methods have already become a powerful tool for plant breeding. Since the creation of diversity for selection is one of the main directions in breeding, multiplex editing of a potentially unlimited number of genes using the CRISPR/Cas technology provided a strategy for the rapid production of genetic diversity in the breeding process.

Another important advantage of CRISPR/ Cas technology is a relatively low cost. So, if the development and promotion of a GM product can cost up to $\$ 150$ million, CRISPR/Cas using is $\mathbf{9 0} \%$ cheaper.

Regarding the regulation of genetically edited plants. The National Academy of Sciences of the USA called genome changes the most important breakthrough that will allow feeding more and more of the world's population in the face of climate change.

By decision of the US Department of Agriculture, genome edited plants (with the exception of parasitic plants), "which could otherwise be developed using traditional breeding technologies", and the corresponding foods are not regulated as GMOs [36]. In the United States, thanks to soft regulation, more than 20 plant species from the edited genomes have already been developed, and the first products made from such plants will appear in American stores as early as 2019 (in particular, salad dressings and Granola bars).

At the same time, the EU court ruled (July 25,2018 ) that the products obtained using the
CRISPR/Cas genome editing techniques, in particular plant varieties, are subject to all existing EU regulatory rules and restrictions on cultivation and sale, as well as for genetically modified organisms: they are subject to verification, and food products are labeled [37].

The background is as follows. In 2016, after a request by a coalition of environmental organizations, the French government appealed to the EU court to determine the legal status of living organisms created with the help of pinpoint genome editing (in particular, CRISPR/Cas technology). The scientific community hoped that, since these methods do not use whole genes from other organisms, the court does not equate them to genetic modification. But now, by a decision of the highest court of the EU, organisms modified with CRISPR/Cas and other similar technologies will be subject to the EU Directive 2001, which sets strict safety restrictions and prior regulatory approval for GM products [38].

EuropaBio, the industry association of European biotechnology companies, through its representative, called the court's decision a step back and added that the billions of euros invested by governments and businesses in CRISPR technology in agriculture can no longer bring practical results to farmers.

While citing experts "Nature" notes that CRISPR research in the European Union will continue, but business interest and grantors in the development of such products will decline significantly due to their lack of short-term commercial prospects [39]. The Journal adds that obtaining all the necessary permits for working with GM plants costs an average of $\$ 35$ million in the EU, which will make the development of CRISPR varieties too expensive for small companies and research organizations [40]. As a result of this decision, a number of European companies are already transferring their scientific developments outside the EU to more favorable jurisdictions, in particular to Japan and the USA, where genome editing methods do not fall under the rules for regulating GMOs.

The Flemish Institute for Biotechnology (Vlaams Instituut voor Biotechnologie) (Belgium) initiated the publication of a document calling for European politicians to urgently protect the technology of genome editing [41]. Scientists are deeply concerned that the decision of the EU court deprives them of an indispensable tool for innovative crop production, and farmers - new crops rich in nutrients and compatible with climate change. And the rest of society needs progressive crop produc- 
tion, taking into account current economic and social problems. The verdict of the European Union does not correspond to modern scientific progress, scientists believe. Today, this statement is approved by leading scientists representing more than 90 European research centers and institutes for the study of plants and biological sciences, and new signatories are constantly adding their names to this list. Such restrictive regulation of innovative methods of plant breeding will have unacceptable consequences for Europe and significantly weakens agricultural production in Europe.

Strong support by European research institutes for this position paper is proof of solid consensus among the academic community of life sciences and evidence that we must act to protect innovative technologies in Europe for more sustainable agriculture and food production.

\section{Conclusions}

CRISPR/Cas genome editing technology is one of the most powerful approaches of locusspecific genetic modifications, which has become extensively used in plant breeding due to such advantages as high accuracy and quality, efficiency and technical flexibility, compared to other methods. This available method allows obtaining non-transgenic plants with specified modifications, and it is possible to simultaneously "produce" mutations in several targets. CRISPR/Cas-modifications for 20 types of crops, for more than 150 genes of various characters have already been described.

\section{References}

1. FA0, IFAD, UNICEF, WFP, \& WHO. (2018). The State of food security and nutrition in the world 2018. Building climate resilience for food security and nutrition. Rome: FA0.

2. Transforming our world: the 2030 Agenda for Sustainable Development. (2015). Retrieved from http://www.un.org/ga/search/ view_doc.asp?symbol=A/RES/70/1\&Lang=E

3. Jinek, M., Chylinski, K., Fonfara, I., Hauer, M., Doudna, J., \& Charpentier, E. (2012). A programmable dual-RNA-guided DNA endonuclease in adaptive bacterial immunity. Science, 337(6096), 816-821. doi: 10.1126/science.1225829

4. Govindan, G., \& Ramalingam, S. (2016). Programmable sitespecific nucleases for targeted genome engineering in higher eukaryotes. J. Cell. Physiol., 231(11), 2380-2392. doi: 10.1002/ jсp.25367

5. Ishino, Y., Shinagawa, H., Makino, K., Amemura, M., \& Nakata, A. (1987). Nucleotide sequence of the IAP gene, responsible for alkaline phosphatase isozyme conversion in Escherichia coli, and identification of the gene product. J. Bacteriol., 169(12), 5429-5433. doi: 10.1128/jb.169.12.5429-5433.1987

6. Jansen, R., Embden, J., Gaastra, W., \& Schouls, L. (2002). Identification of genes that are associated with DNA repeats in prokaryotes. Mol. Microbiol., 43(6), 1565-1575. doi: 10.1046/ j.1365-2958.2002.02839.x

7. Sontheimer, E., \& Barrangou, R. (2015). The bacterial origins of the CRISPR genome-editing revolution. Hum. Gene Ther., 26(7), 413-424. doi: 10.1089/hum.2015.091
8. Liu, X., Wu, S., Xu, J., Sui, C., \& Wei, J. (2017). Application of CRISPR/Cas9 in plant biology. Acta Pharm. Sin. B., 7(3), 292302. doi: 10.1016/j.apsb.2017.01.002

9. Arora, L., \& Narula, A. (2017). Gene editing and crop improvement using CRISPR-Cas9 system. Front Plant Sci., 8, 1932. doi: 10.3389/fpls.2017.01932

10. Langner, T., Kamoun, S., \& Belhaj, K. (2018). CRISPR crops: plant genome editing toward disease resistance. Ann. Review Phytopathol., 56, 479-512. doi: 10.1146/annurev-phyto-080417-050158

11. Lundgren, M., Charpentier, E., \& Fineran, P. (Eds.). (2015). CRISPR. Methods and Protocols. New York, USA: Humana Press. doi: 10.1007/978-1-4939-2687-9

12. Jung, C., Capistrano-Gossmann, G., Braatz, J., Sashidhar, N., \& Melzer, S. (2018). Recent developments in genome editing and applications in plant breeding. Plant Breed., 137(1), 1-9. doi: $10.1111 / p b r .12526$

13. Osakabe, Y., Watanabe, T., Sugano, S., Ueta, R., Ishihara, R., Shinozaki, K., \& Osakabe, K. (2016). Optimization of CRISPR/Cas9 genome editing to modify abiotic stress responses in plants. Sci. Rep., 6, 26685. doi: 10.1038/srep26685

14. Ricroch, A., Clairand, P., \& Harwood, W. (2017). Use of CRISPR systems in plant genome editing: toward new opportunities in agriculture. Emerg. Top. Life Sci., 1(2), 169-182. doi: 10.1042/ ETLS20170085

15. Korotkova, A. M., Gerasimova, S. V., Shumny, V. K., \& Khlestkina, E. K. (2017). Crop genes modified using CRISPR/Cas system. Vavilovskii Zhurnal Genetiki i Selekcii [Vavilov Journal of Genetics and Breeding], 21(2), 250-258. doi: 10.18699/VJ17.244

16. Jaganathan, D., Ramasamy, K., Sellamuthu, G., Jayabalan, S., \& Venkataraman, G. (2018). CRISPR for crop improvement: an update review. Front. Plant Sci., 9, 985. doi: 10.3389/ fpls.2018.00985

17. Xu, R., Yang, Y., Qin, R., Li, H., Qiu, C., Li, L., ... Yang, J. (2016). Rapid improvement of grain weight via highly efficient CRISPR/Cas9-mediated multiplex genome editing in rice. J. Genet. Genomics., 43(8), 529-532. doi: 10.1016/j.jgg.2016.07.003

18. Li, M., Li, X., Zhou, Z., Wu, P., Fang, M., Pan, X., ... Li, H. (2016). Reassessment of the four yield-related genes Gn1a, DEP1, GS3, and IPA1 in rice using a CRISPR/Cas9 system. Front. Plant Sci., 7, 377. doi: 10.3389/fpls.2016.0037

19. Shen, L., Wang, C., Fu, Y., Wang, J., Liu, Q., Zhang, X., ... Wang, K. (2018). QTL editing confers opposing yield performance in different rice varieties. J. Integr. Plant Biol., 60(2), 89-93. doi: $10.1111 /$ jipb.12501

20. Lu, Y., \& Zhu, J. (2017). Precise editing of a target base in the rice genome using a modified CRISPR/Cas9 system. Mol. Plant., 10(3), 523-525. doi: 10.1016/j.molp.2016.11.013

21. Zhou, H., He, M., Li, J., Chen, L., Huang, Z., Zheng, S., ... Zhuang, C. (2016). Development of commercial thermosensitive genic male sterile rice accelerates hybrid rice breeding using the CRISPR/Cas9-mediated TMS5 editing system. Sci. Rep., 6, 37395. doi: 10.1038/srep37395

22. Li, Q., Zhang, D., Chen, M., Liang, W., Wei, J., Qi, Y., \& Yuan, Z. (2016). Development of japonica photo-sensitive genic male sterile rice lines by editing carbon starved anther using CRISPR/ Cas9. J. Genet. Genomics., 43(6), 415-419. doi: 10.1016/j.jgg. 2016.04.011

23. Shan, Q., Wang, Y., Li, J., Zhang, Y., Chen, K., Liang, Z., ... Gao, C. (2013). Targeted genome modification of crop plants using a CRISPR-Cas system. Nat. Biotechnol., 31(8), 686-688. doi: $10.1038 /$ nbt.2650

24. Li, J., Sun, Y., Du, J., Zhao, Y., \& Xia, L. (2017). Generation of targeted point mutations in rice by a modified CRISPR/Cas9 system. Mol. Plant., 10(3), 526-529. doi: 10.1016/j.molp.2016.12.001

25. Xie, K., \& Yang, Y. (2013). RNA-guided genome editing in plants using a CRISPR-Cas system. Mol. Plant., 6(6), 1975-1983. doi: $10.1093 / \mathrm{mp} / \mathrm{sst119}$

26. Shen, L., Hua, Y., Fu, Y. Li, J., Liu, Q., Jiao, X., ... Wang, K. (2017). Rapid generation of genetic diversity by multiplex CRISPR/ 
Cas9 genome editing in rice. Sci. China Life Sci., 60(5), 506515. doi: 10.1007/s11427-017-9008-8

27. Sun, Y., Zhang, X., Wu, C., He, Y., Ma, Y., Hou, H., ... Xia, L. (2016). Engineering herbicide-resistant rice plants through CRISPR/Cas9mediated homologous recombination of acetolactate synthase. Mol. Plant., 9(4), 628-631. doi: 10.1016/j.molp.2016.01.001

28. Shimatani, Z., Kashojiya, S., Takayama, M., Terada, R., Arazoe, T., Ishii, H., ... Kondo, A. (2017). Targeted base editing in rice and tomato using a CRISPR-Cas9 cytidine deaminase fusion. Nat. Biotechnol., 35(5), 441-443. doi: 10.1038/nbt.3833

29. Nieves-Cordones, M., Mohamed, S., Tanoi, K., Kobayashi, N., Takagi, K., Vernet, A., ... Véry, A. (2017). Production of low-Cs+ rice plants by inactivation of the $\mathrm{K}+$ transporter OsHAK1 with the CRISPR-Cas system. Plant J., 92(1), 43-56. doi: 10.1111/tpj.13632

30. Mao, X., Zheng, Y., Xiao, K., Wei, Y., Zhu, Y., Cai, Q., ... Zhang, J. (2018). 0sPRX2 contributes to stomatal closure and improves potassium deficiency tolerance in rice. Biochem. Biophys. Res. Commun., 495(1), 461-467. doi: 10.1016/j.bbrc.2017.11.045

31. Liu, D., Chen, X., Liu, J., Ye, J., \& Guo, Z. (2012). The rice ERF transcription factor 0sERF922 negatively regulates resistance to Magnaporthe oryzae and salt tolerance. J. Exp. Bot., 63(10), 3899-3912. doi: 10.1093/jxb/ers079

32. Zhou, J., Peng, Z., Long, J., Sosso, D., Liu, B., Eom, J., ... Yang, B. (2015). Gene targeting by the TAL effector PthXo2 reveals cryptic resistance gene for bacterial blight of rice. Plant $\mathrm{J}$. 82(4), 632-643. doi: 10.1111/tpj.12838

33. Wang, F., Wang, C., Liu, P., Zhang, Q., Li, L., Zhong, C., ... Zhao, K. (2016). Enhanced rice blast resistance by CRISPR/Cas9targeted mutagenesis of the ERF transcription factor gene OsERF922. PLOS ONE, 11(4), e0154027. doi: 10.1371/journal. pone. 0154027

34. Lowder, L., Zhang, D., Baltes, N., Paul, J., Tang, X., Zheng, X., ... Qi, Y. (2015). A CRISPR/Cas9 toolbox for multiplexed plant genome editing and transcriptional regulation. Plant Physiol., 169(2), 971-985. doi: 10.1104/pp.15.00636

35. Zhang, Z., Mao, Y., Ha, S., Liu, W., Botella, J., \& Zhu, J. (2016). A multiplex CRISPR/Cas9 platform for fast and efficient editing of multiple genes in Arabidopsis. Plant Cell Rep., 35(7), 15191533. doi: 10.1007/s00299-015-1900-z

36. Secretary Perdue Issues USDA Statement on Plant Breeding Innovation. Press Release No 0070.18. (2018). Retrieved from https:// www.usda.gov/media/press-releases/2018/03/28/secretaryperdue-issues-usda-statement-plant-breeding-innovation

37. Court of Justice of the European Union. (2018). Organisms obtained by mutagenesis are GMOs and are, in principle, subject to the obligations laid down by the GMO Directive. Press release No 111/18. Retrieved from https://curia.europa.eu/jcms/upload/docs/application/pdf/2018-07/cp180111en.pdf

38. Directive 2001/18/EC of the European Parliament and of the Council of 12 March 2001 on the deliberate release into the environment of genetically modified organisms and repealing. Council Directive 90/220/EEC. L 106/2 EN. Retrieved from https:// eur-lex.europa.eu/resource.html?uri=cellar:303dd4fa-07a84d20-86a8-0baaf0518d22.0004.02/D0C_1\&format=PDF

39. Wight, A. (2018). Strict EU ruling on gene-edited crops squeezes science. Nature, 56(7729), 15-16. doi: 10.1038/d41586018-07166-7

40. Kupferschmidt, K. (2018). EU verdict on CRISPR crops dismays scientists. Science, 361(6401), 435-436. doi: 10.1126/science.361.6401.435

41. Regulating genome edited organisms as GMOs has negative consequences for agriculture, society and economy (2018). Retrieved from https://www.cnb.csic.es/images/temporal/Position_paper_ on_the_ECJ_ruling_on_CRISPR_22_Oct_2018.pdf

\section{Використана література}

1. The State of food security and nutrition in the world 2018. Building climate resilience for food security and nutrition / FAO, IFAD, UNICEF, WFP and WHO. Rome : FA0, 2018. 202 p.
2. Transforming our world: the 2030 Agenda for Sustainable Development.URL:http://www.un.org/ga/search/view_doc.asp?symbol= A/RES/70/1\&Lang $=E$

3 Jinek M., Chylinski K., Fonfara I. et al. A programmable dualRNA-guided DNA endonuclease in adaptive bacterial immunity. Science. 2012. Vol. 337, Iss. 6096. P. 816-821. doi: 10.1126/ science.1225829

4. Govindan G., Ramalingam S. Programmable site-specific nucleases for targeted genome engineering in higher eukaryotes. $J$. Cell. Physiol.2016. Vol.231, Iss. 11. P. 2380-2392. doi: 10.1002/ jcp. 25367

5. Ishino Y., Shinagawa H., Makino K. et al. Nucleotide sequence of the iap gene, responsible for alkaline phosphatase isozyme conversion in Escherichia coli, and identification of the gene product. J. Bacteriol. 1987. Vol. 169, Iss. 12. P. 5429-5433. doi: 10.1128/jb.169.12.5429-5433.1987

6. Jansen R., Embden J., Gaastra W., Schouls L. Identification of genes that are associated with DNA repeats in prokaryotes. Mol. Microbiol. 2002. Vol. 43, Iss. 6. P. 1565-1575. doi: 10.1046/j.1365-2958.2002.02839.x

7. Sontheimer E., Barrangou R. The bacterial origins of the CRISPR genome-editing revolution. Hum. Gene Ther. 2015. Vol. 26, Iss. 7. P. 413-424. doi: 10.1089/hum.2015.091

8. Liu X., Wu S., Xu J. et al. Application of CRISPR/Cas9 in plant biology. Acta Pharm. Sinica B. 2017. Vol. 7, Iss. 3. P. 292-302. doi: 10.1016/j.apsb.2017.01.002

9. Arora L., Narula A. Gene editing and crop improvement using CRISPR-Cas9 system. Front Plant Sci. 2017. Vol. 8: 1932. doi: 10.3389/fpls.2017.01932

10. Langner T., Kamoun S., Belhaj K. CRISPR crops: plant genome editing toward disease resistance. Ann. Review Phytopathol. 2018. Vol. 56. P. 479-512. doi: 10.1146/annurev-phyto080417-050158

11. CRISPR. Methods and Protocols / M. Lundgren, E. Charpentier, P. Fineran (eds). New York, USA : Humana Press, 2015. doi: 10.1007/978-1-4939-2687-9

12. Jung C., Capistrano-Gossmann G., Braatz J. et al. Recent developments in genome editing and applications in plant breeding. Plant Breed. 2018. Vol. 137, Iss. 1. P. 1-9. doi: 10.1111/pbr.12526

13. Osakabe Y., Watanabe T., Sugano S. et al. Optimization of CRIS PR/Cas9 genome editing to modify abiotic stress responses in plants. Sci. Rep. 2016. Vol. 6: 26685. doi: 10.1038/srep26685

14. Ricroch A., Clairand P., Harwood W. Use of CRISPR systems in plant genome editing: toward new opportunities in agriculture. Emerg. Top. Life Sci. 2017. Vol. 1, Iss. 2. P. 169-182. doi: 10.1042/ETLS20170085

15. Короткова А. М., Герасимова С. В., Шумный В. К., Хлесткина Е. К. Гены сельскохозяйственных растений, модифицированные с помощью системы CRISPR/Cas. Вавиловский журнал генетики и селекции. 2017. Т. 21, № 2. С. 250-258. doi: 10.18699/ VJ17.244

16. Jaganathan D., Ramasamy K., Sellamuthu G. et al. CRISPR for crop improvement: an update review. Front. Plant Sci. 2018. Vol. 9: 985. doi: 10.3389/fpls.2018.00985

17. Xu R., Yang Y., Qin R. et al. Rapid improvement of grain weight via highly efficient CRISPR/Cas9-mediated multiplex genome editing in rice. J. Genet. Genomics. 2016. Vol. 43, Iss. 4. P. 529-532. doi: 10.1016/j.jgg.2016.07.003

18. Li M., Li X., Zhou Z. et al. Reassessment of the four yield-related genes Gn1a, DEP1, GS3, and IPA1 in rice using a CRISPR/ Cas9 system. Front. Plant Sci. 2016. Vol. 7: 377. doi: 10.3389/ fpls.2016.0037

19. Shen L., Wang C., Fu Y. et al. QTL editing confers opposing yield performance in different rice varieties. J. Integr. Plant Biol. 2018. Vol. 60, Iss. 2. P. 89-93. doi: 10.1111/jipb.12501

20. Lu Y., Zhu J. Precise editing of a target base in the rice genome using a modified CRISPR/Cas9 system. Mol. Plant. 2017. Vol. 10, Iss. 3. P. 523-525. doi: 10.1016/j.molp.2016.11.013

21. Zhou H., He M., Li J. et al. Development of commercial thermosensitive genic male sterile rice accelerates hybrid 
rice breeding using the CRISPR/Cas9-mediated TMS5 editing system. Sci. Rep. 2016. Vol. 6: 37395. doi: 10.1038/srep37395

22. Li Q., Zhang D., Chen M. et al. Development of japonica photosensitive genic male sterile rice lines by editing carbon starved anther using CRISPR/Cas9. J. Genet. Genomics. 2016. Vol. 43, Iss. 6. P. 415-419. doi: 10.1016/j.jgg.2016.04.011

23. Shan Q., Wang Y., Li J. et al. Targeted genome modification of crop plants using a CRISPR-Cas system. Nat. Biotechnol. 2013. Vol. 31, Iss. 8. P. 686-688. doi: 10.1038/nbt.2650

24. Li J., Sun Y., Du J. et al. Generation of targeted point mutations in rice by a modified CRISPR/Cas9 system. Mol. Plant. 2017. Vol. 10, Iss. 3. P. 526-529. doi: 10.1016/j.molp. 2016.12.001

25. Xie K., Yang Y. RNA-guided genome editing in plants using a CRISPR-Cas system. Mol. Plant. 2013. Vol. 6, Iss. 6. P. 19751983. doi: $10.1093 / \mathrm{mp} / \mathrm{sst} 119$

26. Shen L., Hua Y., Fu Y. et al. Rapid generation of genetic diversity by multiplex CRISPR/Cas9 genome editing in rice. Sci. China Life Sci. 2017. Vol. 60, Iss. 5. P. 506-515. doi: 10.1007/ s11427-017-9008-8

27. Sun Y., Zhang X., Wu C. et al. Engineering herbicide-resistant rice plants through CRISPR/Cas9-mediated homologous recombination of acetolactate synthase. Mol. Plant. 2016. Vol. 9, Iss. 4. P. 628-631. doi: 10.1016/j.molp.2016.01.001

28. Shimatani Z., Kashojiya S., Takayama M. et al. Targeted base editing in rice and tomato using a CRISPR-Cas9 cytidine deaminase fusion. Nat. Biotechnol. 2017. Vol. 35, Iss. 5. P. 441-443. doi: 10.1038/nbt.3833

29. Nieves-Cordones M., Mohamed S., Tanoi K. et al. Production of low-Cs+ rice plants by inactivation of the $\mathrm{K}+$ transporter OsHAK1 with the CRISPR-Cas system. Plant J. 2017. Vol. 92, Iss. 1. P. 43-56. doi: 10.1111/tpj.13632

30. Mao X., Zheng Y., Xiao K. et al. OsPRX2 contributes to stomatal closure and improves potassium deficiency tolerance in rice. Biochem. Biophys. Res. Commun. 2018. Vol. 495, Iss. 1. P. 461467. doi: 10.1016/j.bbrc.2017.11.045

31. Liu D., Chen X., Liu J. et al. The rice ERF transcription factor OsERF922 negatively regulates resistance to Magnaporthe oryzae and salt tolerance. J. Exp. Bot. 2012. Vol. 63, Iss. 10. P. 3899-3911. doi: 10.1093/jxb/ers079
32. Zhou J., Peng Z., Long J. et al. Gene targeting by the TAL effector PthXo2 reveals cryptic resistance gene for bacterial blight of rice. Plant J. 2015. Vol. 82, Iss. 4. P. 632-643. doi: 10.1111/tpj.12838

33. Wang F., Wang C., Liu P. et al. Enhanced rice blast resistance by CRISPR/Cas9-targeted mutagenesis of the ERF transcription factor gene OsERF922. PLOS ONE. 2016. Vol. 11, Iss. 4: e0154027. doi: 10.1371/journal.pone.0154027

34. Lowder L., Zhang D., Baltes N. et al. A CRISPR/Cas9 toolbox for multiplexed plant genome editing and transcriptional regulation. Plant Physiol. 2015. Vol. 169, Iss. 2. P. 971-985. doi: 10.1104/pp.15.00636

35. Zhang Z., Mao Y., Ha S. et al. A multiplex CRISPR/Cas9 platform for fast and efficient editing of multiple genes in Arabidopsis. Plant Cell Rep. 2016. Vol. 35, Iss. 7. P. 1519-1533. doi: 10.1007/s00299-015-1900-z

36. Secretary Perdue Issues USDA Statement on Plant Breeding Innovation. Press Release No 0070.18. URL: https://www.usda. gov/media/press-releases/2018/03/28/secretary-perdueissues-usda-statement-plant-breeding-innovation

37. Organisms obtained by mutagenesis are GMOs and are, in principle, subject to the obligations laid down by the GMO Directive / Court of Justice of the European Union. Press release No 111/18. URL: https://curia.europa.eu/jcms/ upload/docs/application/pdf/2018-07/cp180111en.pdf

38. Directive 2001/18/EC of the European Parliament and of the Council of 12 March 2001 on the deliberate release into the environment of genetically modified organisms and repealing. Council Directive 90/220/EEC. URL: https://eur-lex.europa. $\mathrm{eu} /$ resource.html? uri $=$ cellar:303dd4fa-07a 8-4d20-86a Obaaf0518d22.0004.02/DOC_1\&format=PDF

39. Wight A. Strict EU ruling on gene-edited crops squeezes science. Nature. 2018. Vol. 56, Iss. 7729. P. 15-16. doi: 10.1038/ d41586-018-07166-7

40. Kupferschmidt K. EU verdict on CRISPR crops dismays scientists. Science. 2018. Vol. 361, Iss. 6401. P. 435-436. doi: 10.1126/ science.361.6401.435

41. Regulating genome edited organisms as GMOs has negative consequences for agriculture, society and economy. URL: https://www.cnb.csic.es/images/temporal/Position_ paper_on_the_ECJ_ruling_on_CRISPR_22_0ct_2018.pdf

\section{УДК 577.21:575.22:581.6}

Волкова Н. Е.", Захарова 0. 0. CRISPR/Саs-технологія для поліпшення сільськогосподарських рослин (огляд). Plant Varieties Studying and Protection. 2019. T. 15, № 1. С. 24-31. https://doi.org/10.21498/25181017.15.1.2019.162478

ТОВ «Котекна Україна Лімітед», вул. Люстдорфська дорога, 140-A, м. 0деса, 65114, Україна, "e-mail: natalia.volkova@cotecna.com

Мета. Проаналізувати сучасний стан поліпшення сільськогосподарських культур за допомогою CRISPR/Cas-технології генетичної модифікації геномів. Результати. Наведено історію розвитку технологій редагування генома із сайтспецифічними ендонуклеазами. Проаналізовано сучасний стан створення сортів рослин за допомогою цих технологій. Показано, що технологія редагування генів CRISPR/Cas уже адаптована для 20 видів сільськогосподарських культур для більш ніж 150 генів, пов'язаних із важливими ознаками. Практичне впровадження цієї технології представлено на прикладі рису, для якого спостерігається найбільший прогрес у дослідженнях та використанні CRISPR/Cas-технології: модифіковано найбільшу кількість генів - 78; отримано понад 20 сортів. Редаговано гени рису, що пов'язані з такими ознаками, як розмір зерна, озерненість, висота рослини, чоловіча стерильність, накопичення цезію, толерантність до абіотичних та біотичних стресів, стійкість до гербіцидів. Підкреслено можливість мультиплексного редагування потенційно необмеженої кількості генів. Обговорено ситуацію щодо регулювання рослин, створених за технологією реда- гування генома: за рішенням суду Європейського Союзу (ЕС) на продукцію, отриману за допомогою методик редагування геномів, зокрема сорти рослин, поширюються всі нормативні правила та обмеження ЄС на вирощування і продаж, що й на ГМ0, тоді як Міністерство сільського господарства США визначило, що такі рослини, крім рослин-паразитів, не регулюються як ГМО. Надано інформацію про заяву, схвалену провідними вченими, які представляють понад 90 європейських дослідницьких центрів та інститутів з досліджень рослин та біологічних наук, у підтримку технології редагування геномів. Висновки. Серед технологій редагування генома CRISPR/Cas-технологія $€$ одним із найпотужніших підходів, який став дуже швидко застосовуватися в селекції рослин завдяки таким перевагам над іншими методами як висока точність і якість, ефективність та технічна гнучкість, відносно низька вартість. Цей доступний метод дає змогу отримувати нетрансгенні рослини із заданими модифікаціями, причому можна одночасно «виробляти» мутації в кількох мішенях.

Ключові слова: генетична модифікація; редагування генома; сайт-специфічні ендонуклеази; нокаут генів. 
УДК 577.21:575.22:581.6

Волкова Н. Э.", Захарова 0. А. CRISPR/Саs-технология для улучшения сельскохозяйственных растений (обзор) // Plant Varieties Studying and Protection. 2019. T.15, №1. C. 24-31. https://doi.org/10.21498/2518-1017.15.1.2019.162478

000 «Котекна Украина Лимитед», ул. Люстдорфская дорога, 140-A, г. Одесса, 65114, Украина,

*e-mail: natalia.volkova@cotecna.com

Цель. Проанализировать современное состояние улучшения сельскохозяйственных культур с помощью CRISPR/Cas-технологии генетической модификации геномов. Результаты. Представлена история развития технологий изменения генома с сайт-специфическими эндонуклеазами. Проанализировано современное состояние создания генноредактированных растений. Показано, что технология изменения генов CRISPR/Cas уже адаптирована для 20 видов сельскохозяйственных культур для более 150 генов различных признаков. Практическое внедрение этой технологии дано на примере риса, для которого наблюдается наибольший прогресс в исследованиях и использовании CRISPR/ Cas-технологии: модифицировано наибольшее число генов - 78; получено более 20 генноредактированных сортов. Отредактировано гены риса, связанные с такими признаками, как размер зерна, озерненность, высота растения, мужская стерильность, накопление цезия, толерантность к абиотическим и биотическим стрессам, устойчивость к гербицидам. Подчеркнута возможность мультиплексного редактирования потенциально неограниченного числа генов. Представлена информация по регулированию растений, созданных по технологии редактирования генома: по решению суда Европейско-

го Союза (EC) на продукцию, полученную с помощью методик редактирования геномов, в частности сорта растений, распространяются все нормативные правила и ограничения ЕС на выращивание и продажу, что и на ГМ0, тогда как решением Министерства сельского хозяйства США такие растения, кроме растений-паразитов, не регулируются как ГМО. Приведена информация о заявлении, подписанном ведущими учеными, представляющими более 90 европейских исследовательских центров и институтов по исследованиям растений и биологических наук, в поддержку технологии редактирования геномов. Выводы. Среди технологий редактирования генома CRISPR/Cas-технология является одним из самых мощных подходов, который стал очень быстро применяться в селекции растений благодаря таким преимуществам перед другими методами, как высокая точность и качество, эффективность и техническая гибкость, относительно низкая стоимость. Этот доступный метод позволяет получать нетрансгенные растения с заданными модификациями, причем можно одновременно «производить» мутации в нескольких мишенях.

Ключевые слова: генетическая модификация; редактирование генома; сайт-специфические эндонуклеазы; нокаут генов. 